\title{
Leadership in the University Student Environment: How to Become a Person-Oriented Leader
}

Anna V. Zorina

Elabuga Institute of Kazan Federal University, Elabuga, Russia, azorina@mail.ru

Alfiya Sh. Yarullina

Elabuga Institute of Kazan Federal University, Elabuga, Russia, alfiyay@yahoo.com

Leysan A. Akhmetova

Elabuga Institute of Kazan Federal University, Elabuga, Russia, leisan81@mail.ru

Milyausha R. Shaimardanova

Elabuga Institute of Kazan Federal University, Elabuga, Russia, milyausha33@mail.ru

\section{Svetlana R. Nikishina}

Elabuga Institute of Kazan Federal University, Elabuga, Russia, radanisovna@mail.ru

\section{Aygul A. Garipova}

Elabuga Institute of Kazan Federal University, Elabuga, Russia, garipova25@mail.ru

Currently there is a vital need to teach youth to demonstrate leadership skills as well as to work in the competitive market environment. This article is devoted to the problem of leadership training among university students. The sample included 474 students of Kazan Federal University. The project was based on the use of person-oriented interaction between the university tutors and students to help young people overcome the barriers to develop leadership qualities while being engaged in the organizational activities. In the first phase, the participants' levels of leadership qualities, organizational inclination, and communication skills were determined. The experimental stage was aimed at teaching student organizers create a positive atmosphere in the group being guided by the principles of personoriented interaction between a leader and his followers. The experiment has demonstrated that collaboration of people with a high level of leadership qualities and those ones with a low level of leadership qualities do not give positive results. Collaboration with the university tutors gave support to the student participants and helped them develop the traits of a leader.

Keywords: leadership qualities, student organizers, person-orientated interaction, organizational instruction, organizational inclination, communication skills

Citation: Zorina, A. V., Yarullina, A. S., Akhmetova, L. A., Shaimardanova, M. R., Nikishina, S. R. \& Garipova, A. A. (2018). Leadership in the University Student Environment: How to Become a Person-Oriented Leader. International Journal of Instruction, 11(4), 271-286. https://doi.org/10.12973/iji.2018.11418a 


\section{INTRODUCTION}

In recent years, the interest towards leadership in a university student community has grown significantly (Haley et al., 2018; Heinecke et al., 2016; Webb, 2018; ZamaniGallaher, 2018). The most favorable situations and conditions for encouraging an individual to the leadership positions are explored (Collinson \&Tourish, 2015; Ellemers, De Gilder \& Haslam, 2004); new methods for the formation of leadership qualities and development of the students' leadership potential are created (Day et al., 2014; Jones et al., 2012; Moorosi, 2014). The reason for student leadership being center of attention of higher education systems and management is because of the growing discontent among the prospective employers (Browne and Rayner, 2015; Shakir, 2009). They note high level of proficiency but lack of communication and leadership skills of future employees, which is one of the reasons of high level of unemployment among the youth (Piccolo et al., 2010).

Leadership development programs are designed to help university students develop their leadership skills (Chai, 2015), receive the necessary tools of being a leader (Chesnutand Tran-Johnson, 2013), have some hands-on experience in leading a team (Ozgen et. al., 2013) which are to allow young people to deal with leadership challenges in their future career. Moreover, adult leadership differs from youth leadership and adult leaders differ from student leaders because youth leaders act in a different way to adults (Kress, 2006; Macneil, 2006).Currently not enough studies exist on what exactly can inspire young people to follow their peers. It is still unknown why students choose some of their classmates to follow and do not want to build leader-follower relationships with other members of the student group (Murphy and Johnson 2011; Ward and Ellis 2008). Young people follow a leader to achieve certain immediate goals (Kassinelly, 1966; Krichevskiy, 1993; Orekhov, 2003 etc.). E. Bogardus, a representative of the concept of "leadership qualities", believed to become a leader has to have certain sets of leadership traits such as 'intelligence', 'sense of humor', 'strength of character', 'ability to guide others', 'energy', etc. (Bogardus, 1948).

A leader is responsible for establishing a friendly atmosphere in the group to encourage all members of the group to work together without feeling intimidated, frightened or insecure (Blanchard, 2010). A leader helps each member of the group succeed, inspires them, and encourages them to achieve their most important goals (Adler, 2000; Meneghetti, 2004). A good student leader needs to be able to make use of both his character and leadership qualities in order to answer the needs of his followers and to effect impact on other students' lives (Chai, 2015).

Mortenson's opinion is that without understanding of what leadership means for young people, the process of engaging students in leadership development is difficult. This position is considered extremely complicated (Mortenson et al., 2014). It is naive to assume that today's youth leadership is the same as it used to be the previous generations. The hypothesis is that university students might have a new set of leadership qualities, which differed from the one, which had been created a couple of decades ago. 
Thus, the aim of this study is to find the ways of helping students who demonstrate a low level of leadership qualities to develop leadership skills and to overcome the barriers, which prevent them from being leaders.

\section{METHOD}

\section{Participants}

Four hundred and seventy-four students of Elabuga Institute of Kazan (Volga Region) Federal University (two hundred and forty six second-year students and two hundred and twenty eight third-year students) took part in the first part of the study. The distribution of students among faculties was as follows: one hundred and eighty six $(39.2 \%)$ students of the Faculty of Mathematics and Natural Science, one hundred and fifty five $(32.7 \%)$ students of the Faculty of Philology and History, and one hundred and thirty tree $(28.1 \%)$ students of Faculty of Foreign Languages. Male students represented $37,3 \%$, female $-62,7 \%$ respectively.

\section{Sampling technique}

The participants were asked to look through the list of the leadership qualities and to make changes according to their own ideas about the qualities a person needs to obtain to act as a leader. The students could cross out some qualities if they found them unnecessary for a modern leader and add five-six more qualities to the list. The students had 10-15 minutes for each test.

\section{Data collection tools}

The students were offered another list of 25 more qualities to choose from. The participants were given 5-7 minutes to do the task. Furthermore, the participants were asked to complete two questionnaires, developed by A. V. Batarshev (2001), to find out their levels of leadership qualities, organizational inclinations, and communicative skills.

The aim of the processing of the results is to receive the index numbers of communication skills and organizational inclinations. To do this, participants' answers were compared with the decoder and count the number of coincidence (Table 1).

Table 1

Decoder

\begin{tabular}{lll}
\hline Inclinations / Skills & Answers & \\
\cline { 2 - 3 } & Positive & Negative \\
\hline Communication Skills & $\sum(+)$ of the $1^{\text {st }}$ column & $\sum(+)$ of the $3^{\text {rd }}$ column \\
\hline Organizational Inclination & $\sum(+)$ of the $2^{\text {nd }}$ column & $\sum(+)$ of the $4^{\text {th }}$ column \\
\hline
\end{tabular}

To determine the levels of communication skills and organizational inclinations it is necessary to work out their coefficients. To do this, the following formulas were used $: K_{\text {com }}=\frac{K_{x}}{20} ; K_{\text {org }}=\frac{\theta_{x}}{20} ; K_{\text {com }}-$ coefficient of communication; $K_{\text {org }}-$ coefficient of organizational inclinations; $K_{x}$ and $O_{x}$ - quantity of answers which coincide with the 
decoder. To find out the participants' level of organizational inclinations and communication skills, special rating scale was applied (Table 2).

Table 2

The rating scale of communication skills and organizational inclinations

\begin{tabular}{llll}
\hline & & Rating Scale & Levels \\
\hline $\boldsymbol{K}_{\text {com }}$ & $\boldsymbol{K}_{\text {org }}$ & & \\
\hline $0,10-0,45$ & $0,2-0,55$ & 1 & Lowest Level (1-15 points) \\
\hline $0,46-0,55$ & $0,56-0,65$ & 2 & Low level (15-25) \\
\hline $0,56-0,65$ & $0.66-0,70$ & 3 & Average Level (26-35) \\
\hline $0,66-0,75$ & $0,71-0,80$ & 4 & High Level (36-40) \\
\hline $0,75-1,00$ & $0,81-1,00$ & 5 & Highest Level (36-40 points) \\
\hline
\end{tabular}

The test on leadership level consists of 50 statements. The students read the statements and choose the best option $-a$ orb. A participant receives 1 point for each answer, which coincides with the answer in the keys.

\section{Procedure of implementation}

The university activity is diverse. It includes educational activities, research and extracurricular activities, creativity, organizational activities, etc. Being engaged in social aspects of university life and taking part in various organizational activities, students have an opportunity to advance their personal development (Huang and Chang, 2004).In this research, the organizational activity of students is considered in the most effective way of promoting individuals to the leading positions and forming the necessary leadership qualities for this (Haber, 2011). Participation of students in different organizational activities helps form and develop the system of leadership qualities and leadership skills for the majority of students, including those whose leadership qualities are not sufficiently formed. Organizational activities of students require them to be active, show initiative, and to be subtle psychologists - to be able to influence people, to gain their support and, at the same time, to respect their desires, their interests, and to try to understand and accept their point of view (Bergman and Wangby, 2014). One can note that student organizers act as leaders. Their main aim is to create a favorable environment to achieve the objectives. As it has been noted before, the experiment was done in the period September 2016 - February 2018.During the practical experimental phases both the researches and the students faced a number of difficulties. Firstly, the participants who had accepted the offer to take part in the experiment as student organizers found it very difficult to play the role of leaders. Nobody was successful from the very start. They did not feel at ease with the groups of first-year student they worked in. Since the participants had no experience of acting as organizers, they were helped by those students who had already been engaged in organizing different events but this help did not make any difference for the participants. Some of them lost interest and left the project. 


\section{FINDINGS}

\section{First Phase}

According to the results of the survey, the students excluded 2 qualities from the list of leadership qualities they had been offered to examine. The respondents found such qualities as "practicality" and "depth of mind" of no use for a leader, but they added such qualities as "an ability to persuade other people"(424 students - 89.5 $\%$ );“"emotional appeal" (409 students - 86.3\%); "self-confidence" (398 students -84 $\%$ ); "intelligence" (384 students $-81 \%$ ); "determination" (377 students $-79.5 \%$ ); "an ability to establish a positive atmosphere in the group" (369 students $-77.8 \%$ ). The list of 15 leadership qualities became the main direction in our pilot experiment. Further, the participants' levels of leadership qualities, communication skills, and organizational inclinations were defined. The results of the survey are shown in Table 3.

Table 3

Levels of leadership qualities, organizational inclinations, and communication skills

\begin{tabular}{|c|c|c|c|}
\hline $\begin{array}{l}\text { Levels of Organizational } \\
\text { Inclination and } \\
\text { Communication Skills }\end{array}$ & $\begin{array}{l}\text { Number of } \\
\text { Students }(\%)\end{array}$ & $\begin{array}{l}\text { Levels of Leadership } \\
\text { Qualities }\end{array}$ & $\begin{array}{l}\text { Number of } \\
\text { Students }(\%)\end{array}$ \\
\hline \multirow{4}{*}{$\begin{array}{l}\text { The Highest Level } \\
\text { ( } 5 \text { points) }\end{array}$} & \multirow{4}{*}{15.6} & the highest & - \\
\hline & & High & 1.7 \\
\hline & & Average & 13.9 \\
\hline & & Low & - \\
\hline \multirow{4}{*}{$\begin{array}{l}\text { High Level } \\
\text { (4 points) }\end{array}$} & \multirow{4}{*}{32.3} & Highest & 0.2 \\
\hline & & High & 1.9 \\
\hline & & Average & 16.7 \\
\hline & & Low & 13.5 \\
\hline \multirow{4}{*}{$\begin{array}{l}\text { Average Level } \\
\text { ( } 3 \text { points) }\end{array}$} & \multirow{4}{*}{27,2} & Highest & - \\
\hline & & High & - \\
\hline & & Average & 14.6 \\
\hline & & Low & 12.5 \\
\hline \multirow{4}{*}{$\begin{array}{l}\text { Low Level } \\
\text { ( } 2 \text { points) }\end{array}$} & \multirow{4}{*}{24.9} & Highest & - \\
\hline & & High & - \\
\hline & & average & - \\
\hline & & Low & 25 \\
\hline \multirow{4}{*}{$\begin{array}{l}\text { Lowest Level } \\
\text { (1 point) }\end{array}$} & \multirow{4}{*}{-} & Highest & - \\
\hline & & High & - \\
\hline & & Average & - \\
\hline & & Low & - \\
\hline
\end{tabular}

For our further study the two hundred and forty-two $(51.1 \%)$ students was chosen. According to the questionnaire, they had demonstrated a low level of leadership qualities but different levels of organizational inclinations. It was recognized that sixtyfour $(26.4 \%)$ had a high level of organizational inclinations, fifty-nine $(24.4 \%)$ respondents demonstrated an average level of organizational inclinations, and one 
hundred and nineteen (49.2\%) people - a low one. These students were offered to try themselves as organizers of various university events, acting as facilitators in freshmen groups to help them get prepared for a number of university extracurricular events (concerts and parties devoted to different foreign and Russian festivals celebrated by today's young people such as Christmas, Halloween, Nowruz, St. Vanentine's Day, Victory Day, Sabantuy; poetry reading events, theatre performances, etc.).

It should be noted that not all students agreed to participate in this project. Of the two hundred and forty-two, chosen for the next stage of the experiment one hundred and eighty-three $(75.6 \%)$ young people agreed to continue their participation in the experiment. The remaining fifty-nine $(24.4 \%)$ students explained their refusal in different ways: lack of free time (twenty-eight people - $12 \%$ ), there is no interest in this kind of activity (twenty people $-8.3 \%$ ), do not consider that they could cope with the set tasks (ten people $-4.1 \%$ ). The majority of the students (thirty-five people $-14.5 \%$ ) who did not accept the offer to participate in this experiment showed an average level of organizational inclination. The other twenty-four $(10 \%)$ students demonstrated a low level of organizational inclination.

\section{Second Phase}

Thus, one hundred and eighty-three students with low level of leadership qualities agreed to participate in the project. Sixty-four of them (35\%) showed a high level of organizational inclination and communication skills, and twenty-five students (13.7 \%) an average level, and ninety-four students $(51.3 \%)$ - a low one. The students with low level of organizational inclination and communication skills (ninety-four students) pointed out that they had never acted as organizers while being at school. They all had problems in communicating both with their peers and with teachers. The majority of them said they had never been offered to take part in organizational activities and that they did not demonstrate any desire to do it since they were afraid of taking responsibilities for performed work. Fifty-nine respondents stressed they had always been too shy and unsure of themselves (see Figure 1).

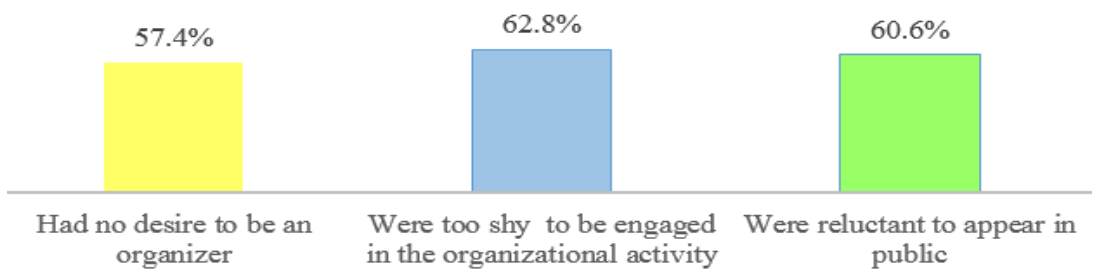

Figure 1

Reasons for not being engaged in the organizational activities at school

These respondents were asked about their reasons to participate in the projects. They all pointed out that they were eager to become more active, and to overcome their shyness and timidity about communicating with other people. Fifty-seven students confessed they had always been reluctant to appear in public or in a big group of people. They all mentioned the necessity of being more initiative, active, self-confident, and highly 
organized to succeed in the future. The respondents stressed they wanted to form some qualities of a leader to be successful in their professional career (see Figure 2).
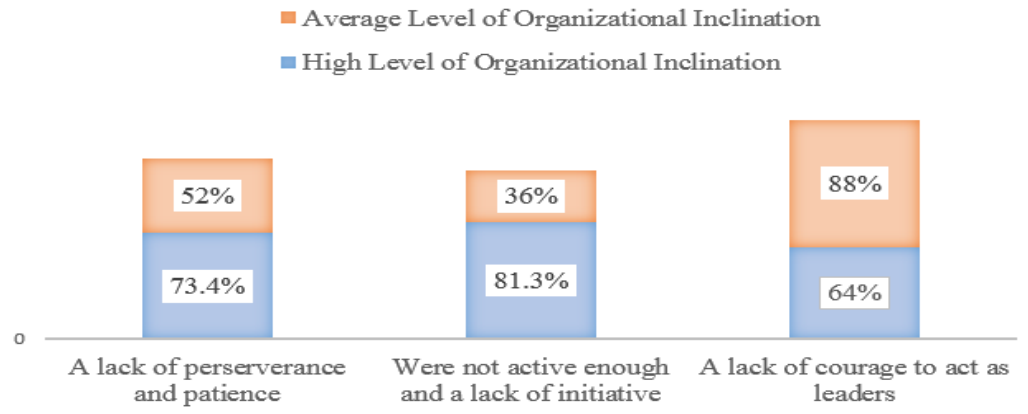

Figure 2

Reasons for being unsuccessful as a leader

The students with high and average levels of organizational inclination, to some extent, had tried to take part in different kind of organizational activities before (some of them did it on their own desire, others were asked to do it by their teachers), but, according to the participants, their actions, as a rule, had been unsuccessful. Forty-seven students $(73.4 \%)$ with a high level of organizational inclinations and $13(52 \%)$ students with an average level explained that they suffered from a lack of perseverance and patience while working within a group of their peers or younger school or university students. Fifty-two young people $(81.3 \%)$ of the high-level group and nine students (36\%) belonging to the average-level group, noted that they were not active enough and they usually suffered from a lack of initiative. Forty-one $(64 \%)$ students of the high-level group and the majority of the participants of the average-level group - twenty-two (88 $\%)$ people - stressed a lack of courage to act as leaders. They pointed out they felt embarrassed, insecure and consider themselves not entitled to "press" on their peer group and to be unable to "tell others what to do".

The monitoring revealed that the majority of the total number of the student organizers (one hundred and fifty-three people - 83, 6\%) found it quite difficult to establish relations within the group. Sometimes it took a lot of time to create a favorable atmosphere for the joint activity or the student leaders did not manage to establish contact with those who acted as their "followers" at all. One hundred and fourteen (62.3 $\%)$ participants noted they were always felt anxiety and uncertainty. They were afraid of being mocked at. Preliminary questioning showed that seventeen of them (46\%) demonstrated a low level of communicative inclinations. They confirmed that it was often difficult for them to establish contact with new people, and even more difficult to make friends with them, to share their emotions and feelings, and even ideas, and, as a rule, they did not receive anything positive in return. As a result, twelve participants (6.6 $\%$ ) with a low level of organizational inclination decided to stop participating in the project. The reasons for their choice are as follows: this is very stressful (58.3\%), very difficult $(25 \%)$, no interest any more $(16.7 \%)$. The other one hundred seventy one students continued their participation in the experiment. These problems were discussed 
with the project participants and the members of the groups where they acted as organizers. Thus, it is important to find out the reasons, which caused a sort of misunderstanding between the young people and prevented the student organizers and their wards from getting closer to each other.

The meetings helped us come to the conclusion that many organizers did not take into account the personality of the people they worked with. Trying only to achieve the main goal - to gather students together in order to discuss and prepare for the event. They forgot about the interests, views, desires and needs of each individual person. They sometimes did not pay attention to the opportunities of the students, their inclinations, blindly appointing those responsible for doing this or that task. As a result, the student organizers faced a lot of problems. The members of their groups demonstrated a lack of initiative and unwillingness to participate in events. They protested against their leaders' rules and ways of building up relationship in the group.

\section{Third Phase}

Initially, one hundred sixty two (34.2\%) students who had shown high and average levels of leadership qualities and a high and the highest levels of leadership inclination to join the project were invited to participate in further research (Table 4).

Table 4

Levels of leadership qualities, organizational inclinations, and communication skills

\begin{tabular}{llll}
\hline $\begin{array}{l}\text { Levels of Organizational Inclination } \\
\text { and Communication Skills }\end{array}$ & $\begin{array}{l}\text { Number of } \\
\text { Students (\%) }\end{array}$ & $\begin{array}{l}\text { Levels of Leadership } \\
\text { Qualities }\end{array}$ & $\begin{array}{l}\text { Number of } \\
\text { Students (\%) }\end{array}$ \\
\hline $\begin{array}{l}\text { The Highest Level } \\
\text { (5 points }\end{array}$ & $46.7 \%$ & high & $4.9 \%$ \\
\cline { 3 - 4 } $\begin{array}{l}\text { High Level } \\
\text { (4 points) }\end{array}$ & $54.3 \%$ & average & $40.7 \%$ \\
\cline { 3 - 4 } & & high & $5.6 \%$ \\
\hline
\end{tabular}

Sixty-three $(38.9 \%)$ students agreed to participate in this phase of the project. All the students admitted they were good at organizing activities, had a rich experience of communicating with peers and students of junior courses, and had successfully acted as leaders in the student environment in the past. These students were members of various student unions and had a reputation of strong leaders in the university student environment. In our research, these new participants are regarded as 'student activists'.

The idea of involving experienced organizers with well-developed leadership qualities produced some good results. The new participants managed to encourage the freshmen's activity. The first-year-students became more interested in what they were doing, but this did not affect the activities of those less active and shyer student organizers. More successful and energetic student activists pushed the shy student organizers to the background, leaving them without an opportunity to prove themselves. Many student activists explained that it was easier for them to do all the work themselves than to "waste their time on explanations and giving advice to the organizers". They only wanted to achieve the goal they had - to make their people carry out the mission they had. They found it boring and unnecessary to share their experience with the student organizers. 


\section{Final Phase}

Considering that the participants might lose their interest in the activities, some other changes were made again. The university tutors and teachers were encouraged to join the project. The formation and development of leadership qualities of students are directly influenced by the example of the teacher and his or her way of building up relationships with the students. The development of interpersonal relations between teachers and students from the position of a coordinator and adviser, the establishment of a person-oriented interaction are possible on condition that a tutor or a teacher tries to explain his/her decision to the students, consulting the students because he or she regards them as part of the group and shows that the students' point of view is important and deserves to be recognized. The tutors' task was to work both with the student leaders and the members of their groups of freshmen. The teachers observed how the student organizers build relationship with their "followers", the attitude and reaction of the freshmen, and at the end of each session discussed the advantages and disadvantages of the meeting with all the participants. The discussions were held individually.

Participating as an adviser, the tutor determines the success of the process of development of leadership qualities among the student organizers, since the teacher does not assume the main role in the process of building interaction between the organizers and those they try to manage. The tutor plays the role of an observer, coach and adviser. Initially, the tutor spends more time with the group and student organizers, showing by example how important it is to establish a person-oriented interaction between the participants, communication of positive results and the joy of joint creativity it will bring. Observations of the course of the experiment and feedback from the participants showed that the introduction of the university tutors and teachers in the project gave positive results. Establishment in the group of person-oriented interaction based on the ideas of partnership, mutual understanding, and acceptance of the personality of each member of the group, allowed the student organizers to significantly improve relations with their groups. In a benevolent atmosphere of co-creation, conditions appeared for the manifestation of activity, initiative, and a creative upsurge appeared.According to the results of the interviews with the participants, they had managed to achieve some good results in respect of the personality development (Figure 3).
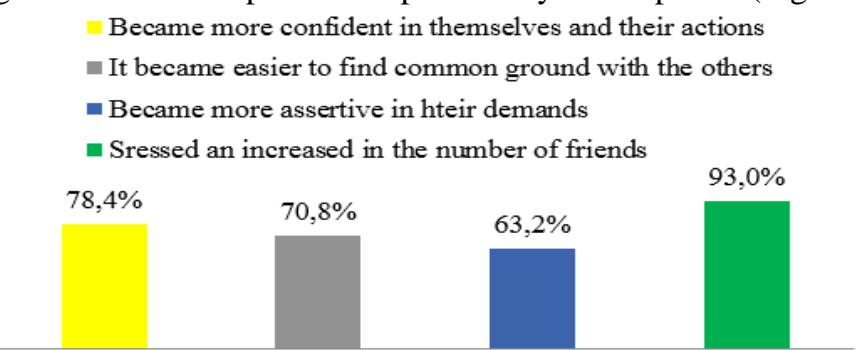

Figure 3

The results of the interview 
The majority of the student organizers (student leaders) - one hundred thirty-four people $(78.4 \%)$ - noted that they had become "more confident in themselves and in their actions". One hundred twenty-one students (70.8\%) stressed that it was easier for them "to find common ground" with the other students and importantly in a conflict situation to restore a positive attitude in the group. One hundred and eight students (63.2\%) noticed that they had become more assertive in their demands, they had "the ability to persuade, to get people "on board" and working to a common objective". One hundred and fifty-nine student leaders $(93 \%)$ stressed the increase in the number of people they were in touch with. They became more communicative, the fear of speaking out their point of view decreased, they became less reticent, both in communicating with peers, and with the teaching staff.

Those students who had acted as "followers" of their student organizers or student leaders also mentioned the changes in the personality of their "bosses" at the end of the experiment. For example, describing the student leaders, the freshmen pointed out that the young organizers had changed for the better by the end of the experiment. Some of them "managed to learn to get rid of their fear to share new ideas" with their "followers". It helped a lot if the freshmen liked the ideas because it helped the student leaders feel more self-confident. Those students who acted as "followers" stressed that they appreciated that some student organizers started sharing their knowledge with them. The freshmen found it both very useful and interesting to communicate with intelligent "bosses". The tutors also stressed the changes in the student leaders in the personality of the student leaders. These are some examples from the tutors' reports on their observation on the participants:

'Masha L. is definitely more active and shows initiative more often now'

'Fanis R. is a very shy student. He used to blush and started mumbling something every time he had to talk to the members of his group. He was always afraid to share his ideas with them. Now he demonstrates less fear and he can pull himself together. Of course, he needs time and more work to achieve his personal goals but he is doing very well indeed'

'Natalya $V$. is a student with a low level of organizational level. Extremely shy and unsociable but she is very intelligent and good-natured. When the freshmen of her group understood that she had a wonderful personality and a high intellectual level, they changed their attitude towards her. It helped the student leader build self-esteem and create a positive atmosphere in the group'

Timur K. has become more sociable. He has made a couple of friends with other students among the freshmen from the group he worked with and the other student leaders. He told me they sometimes spent their free time together playing sport or just sitting in a café. Well done!'

The more detailed results received while talking to the participants, their "followers", and the tutors, are shown it Table 5. 
Table 5

Distribution of students' answers at the final stage

\begin{tabular}{|c|c|c|c|}
\hline Characteristics & $\begin{array}{l}\text { High Level of } \\
\text { Organizational } \\
\text { Inclination and } \\
\text { Communication Skills, } \\
\text { number of students, (\%) } \\
64 \text { students }\end{array}$ & $\begin{array}{l}\text { Average Level of } \\
\text { Organizational } \\
\text { Inclination and } \\
\text { Communication Skills, } \\
\text { number of students, }(\%) \\
25 \text { students }\end{array}$ & $\begin{array}{l}\text { Low Level of } \\
\text { Organizational Inclination } \\
\text { and Communication } \\
\text { Skills, number of students, } \\
(\%) \\
82 \text { students }\end{array}$ \\
\hline Became more active & $46(71.2 \%)$ & $17(68 \%)$ & $54(65.9 \%)$ \\
\hline $\begin{array}{l}\text { Became more } \\
\text { initiative }\end{array}$ & $34(53.1 \%)$ & $14(56 \%)$ & $39(47.6 \%)$ \\
\hline Became more sociable & $54(84.4 \%)$ & $19(76 \%)$ & $67(81.7 \%)$ \\
\hline $\begin{array}{l}\text { Became more } \\
\text { confident }\end{array}$ & $48(75 \%)$ & $17(68 \%)$ & $59(71.9 \%)$ \\
\hline $\begin{array}{l}\text { Became more } \\
\text { independent in } \\
\text { decision-making }\end{array}$ & $36(56.3 \%)$ & $11(44 \%)$ & $21(25.6 \%)$ \\
\hline $\begin{array}{l}\text { Demonstrate an } \\
\text { ability to create a } \\
\text { positive atmosphere in } \\
\text { the group }\end{array}$ & $46(71.9 \%)$ & $17(68 \%)$ & $54(65.9 \%)$ \\
\hline $\begin{array}{l}\text { Demonstrate an } \\
\text { ability to persuade } \\
\text { other people }\end{array}$ & $49(76.6 \%)$ & $17(68 \%)$ & $47(57.3 \%)$ \\
\hline $\begin{array}{l}\text { Demonstrate more } \\
\text { determination in } \\
\text { his/her activity }\end{array}$ & $51(79.7 \%)$ & $19(76 \%)$ & $41(50 \%)$ \\
\hline $\begin{array}{l}\text { Demonstrate } \\
\text { emotional appeal }\end{array}$ & $37(57.8 \%)$ & $11(44 \%)$ & $28(34.1 \%)$ \\
\hline $\begin{array}{l}\text { Demonstrate high } \\
\text { level of organization }\end{array}$ & $41(64.1 \%)$ & $20(80 \%)$ & $61(74.4 \%)$ \\
\hline $\begin{array}{l}\text { Demonstrate } \\
\text { perseverance }\end{array}$ & $49(76.6 \%)$ & $18(72 \%)$ & $47(57.3 \%)$ \\
\hline $\begin{array}{l}\text { Able to show his/her } \\
\text { level of intelligence }\end{array}$ & $47(73.4 \%)$ & $18(72 \%)$ & $48(58.3 \%)$ \\
\hline $\begin{array}{l}\text { Demonstrate a high } \\
\text { level of working } \\
\text { capacity }\end{array}$ & $47(73.4 \%)$ & $22(88 \%)$ & $58(70.7 \%)$ \\
\hline $\begin{array}{l}\text { Demonstrate } \\
\text { observation }\end{array}$ & $44(68.8 \%)$ & $14(56 \%)$ & $35(42.7 \%)$ \\
\hline $\begin{array}{l}\text { Demonstrate a high } \\
\text { level of self-control }\end{array}$ & $39(60.9 \%)$ & $23(92 \%)$ & $64(78 \%)$ \\
\hline
\end{tabular}

\section{DISCUSSION}

Once can note that directly involving students with the low level of leadership qualities to participate in organizational activities will help them develop some leadership qualities, which might be of great importance for them in the future, particularly while building their career. Foreign experience confirms being involved in the organizational activities the participants will have an opportunity to learn more about their personality, about their strengths and weaknesses (Al ShobakiandNaser, 2016; Stensaker, 2015). It will allow them to become self-confident and learn to take responsibility for the joint action and to feel the joy of joint creativity (Gu et al., 2017). 
It is pertinent to point out that incorporation of leadership training programs is obligatory for higher education systems in many countries, which provides opportunities for students to develop their leadership qualities and practice leadership skills. Hence, Malaysian educators explore the possible areas in which the leadership qualities of student leaders can be enhanced to help them become leaders that are more confident in the future, and, thus, to get prepared for a successful career of a leader (Chai, 2015). The importance of incorporation of leadership programs into the learning process is a requirement since Malaysian graduates are expected to have some basic knowledge of leadership theories and to understand the leader's role (Shakir, 2009). In turn, Nordic profile of student focuses primarily on the balancing democratic participation with managerial decision-making (Aasand \& Törnsén, 2016).If the university administration gives up shaping student's leadership skills, it may spark the problems with labor market performance (Ruben et al., 2016). For example, some important management issues affecting Nigerian universities include poor leadership and governance resulting in ineffectiveness, incompetence at all levels, non-realization of national cohesiveness, incessant crime and insecurity, inadequate funding, discontent among the prospective employers, and poor quality of products turned over (Daramolaand Amos, 2016).

During our study, the tutors shared with the student organizers their experience of communication, knowledge and skills on how to get in touch with their group successfully. They helped young leaders realize that person-oriented interaction presupposes a spiritual community, reciprocity of co-creation, and respect for the personal dignity of the partners of communication (Pligin, 2003); creates positive atmosphere and a mutual understanding between a leader and his followers. Such cooperation and co-creation enriches all actors of interaction and is possible only with the establishment of a spiritual community based on respect for the personal dignity of the partners of communication, optimism and a deep understanding of all participants in each other's interaction (Von Eye, 2010; Groves and Burden, 2017).

\section{CONCLUSION}

This research was aimed at exploring the perspectives of the university students with a low level of leadership qualities to develop their organizational inclination and communication skills and thus to develop their leadership traits. Having chosen the organizational kind of activity as the main activity of the experiment, 183 second-year and third-year students were offered to play a role of leaders in the groups of freshmen to help them get prepared for different university events. The experiment has demonstrated that collaboration of people with a high level of leadership qualities and those ones with a low level of leadership qualities do not give positive results. The attempt to involve experienced student leaders into the experiment was not successful since $6.6 \%$ left the project having lost interest and noted that more active and confident participants made them feel even more stressed and less confident. The key finding of the research is that involving student organizers into the person-oriented interaction with the university tutors (who work as part of a student team being more and adviser than an instructor) encourage young people to build relationship with their 'followers' on the principles of person-oriented approach. This method means taking into account the 
needs, interests, and possibilities of other people. Collaboration with the university tutors gave support to the student participants and helped them develop the traits of a leader. $74.9 \%$ of participants were noticed to have become more active. Moreover, young people became less shy in relation of demonstration their knowledge and intelligence; student organizers became more confident. Only $39.8 \%$ became more or less self-independent in decision-making. This low level of achievement, however, should not be viewed negatively since it gives a boost to the researchers for further experiments and finding of innovative methods of developing person's selfindependence in decision making. While the researchers intend to continue doing further research in relation to university student leadership, it is hoped this research findings might raise awareness of other university teachers and educators about the potential of young people with a low level of leadership qualities.

\section{REFERENCES}

Aas, M. \&Törnsén, M. (2016). Examining Norwegian and Swedish leadership training programs in the light of international research. Nordic Studies in Education, 36(02), 173-187.

Adler, A. (2000). To Understand Man's Nature. Translated from German by E. A. Tchipina. SPb.:AcademicheskiyProekt, pp. 253.

Al Shobaki, M. J.\&Naser, S. S. A. (2016). The Dimensions Of Organizational Excellence In The Palestinian Higher Education Institutions From The Perspective Of The Students.

Batarshev, A. V. (2001). Psychodiagnostics of Abilities to Communicate or How to Identify Organizational and Communicative Qualities of a Person. Moscow, VLADOS, pp. 176.

Bergman, L. R. \&Wangby, M. (2014). The person-oriented approach: A short theoretical and practical guide.EestiHaridusteadusteAjakiri, 2(1), 29-49.

Blanchard, K. H. (2010). Leading at a higher level: Blanchard on leadership and creating high performing organizations. FT Press.

Browne, L. \& Rayner, S. (2015). Managing leadership in university reform: data-led decision-making, the cost of learning and déjà vu? Educational Management Administration \& Leadership, 43(2), 290-307.

Chai, M. S. (2015). Personality and leadership qualities among student leader.American Journal of Applied Psychology, 4(3-1), 27-32.

Chesnut, R. \& Tran-Johnson, J. (2013). Impact of a student leadership development program. American Journal of Pharmaceutical Education, 77(10).

Collinson, D.\&Tourish, D. (2015). Teaching leadership critically: New directions for leadership pedagogy. Academy of Management Learning \& Education, 14(4), 576-594. 
Daramola, A. G.\& Amos, T. T. (2016). Management and leadership in Nigerian universities. Futa Journal of Management and Technology, 1(1), 1-16.

Day, D. V.; Fleenor, J. W.; Atwater, L. E.; Sturm, R. E.\& McKee, R. A. (2014). Advances in leader and leadership development: A review of 25 years of research and theory. The Leadership Quarterly, 25(1), 63-82.

Ellemers, N.; De Gilder, D.\& Haslam, S. A. (2004). Motivating individuals and groups at work: A social identity perspective on leadership and group performance. Academy of Management review, 29(3), 459-478.

Groves, W.\& Burden, P. (2017). The impact of personal tutoring on students.

Gu, J.; He, C.\& Liu, H. (2017). Supervisory styles and graduate student creativity: the mediating roles of creative self-efficacy and intrinsic motivation. Studies in Higher Education, 42(4), 721-742.

Haber, P. (2011). Peer education in student leadership programs: Responding to cocurricular challenges. New Directions for Student Services, 133, 65-75.

Haley, K.; Urquhart, C.; Jones, N. C.; Silverman, J.\&Hunzicker, J. (2018). Teacher Leader Reflections: Teacher Leadership and Student Learning. In Teacher Leadership in Professional Development Schools. Emerald Publishing Limited, pp. 99-106.

Heinecke, W. F.; Cole, R.; Han, I.\&Mthethwa, N. (2016). Student activism as civic engagement: Challenging institutional conditions for civic leadership at University of Virginia. In Civic Engagement and Community Service at Research Universities. Palgrave Macmillan, London, pp. 219-239.

Huang, Y.\& Chang, S. (2004). Academic and cocurricular involvement: Their relationship and the best combinations for student growth. Journal of College Student Development, 45, 391-406.

Jones, S.; Lefoe, G.; Harvey, M. \& Ryland, K. (2012). Distributed leadership: A collaborative framework for academics, executives and professionals in higher education. Journal of Higher Education Policy and Management, 34(1), 67-78.

Kassinelly, C. W. (1966). Free activities and interpersonal relations. Hague,pp. 66-67.

Kress, C. A. (2006). Youth leadership and youth development: Connections and questions. New Directions for Youth Development, (109), 45-57.

Krichevskiy, H. L. (1993). If you are a manager...The elements of management psychology in day-to-day work. Moscow: Delo, pp. 348.

Macneil, C. A. (2006). Bridging generations: Applying "adult" leadership theories to youth leadership development. New Directions for Youth Development, pp. 27-44.

Meneghetti, A. (2004). Psychology of a Leader. Moscow: NNBF Ontopsychologiya, pp. 256. 
Moorosi, P. (2014). Constructing a leader's identity through a leadership development programme: An intersectional analysis. Educational Management Administration \& Leadership, 42(6), 792-807.

Mortenson, J.; Lichty, L.; Foster-Fishman, P.; Harfst, S.; Hockin, S.; Warsinske, K.\& Abdullah, K. (2014). Leadership through a youth lens: Understanding youth conceptualizations of leadership. Journal of Community Psychology, 42(4), 447- 462.

Murphy, E.\& Johnson, S. (2011). The benefits of a long-lens approach to leader development: Understanding the seeds of leadership. The Leadership Quarterly, 22, 459-470.

Nelson, A. (2010). Stepping in early to grow great leaders. Leadership in Action, 29(6), 20-24.

Orekhov, V. D. (2003).A way to leadership through developing person's expertise.Staff Management, 3, 48-50.

Ozgen, S.; Sanchez-Galofre, O.; Alabart, J. R.;Medir, M.M. \& Giralt, F. (2013).Assessment of engineering students' leadership competencies. Leadership and Management in Engineering, 13, 65 - 75.

Piccolo, R. F.; Greenbaum, R.; Hartog, D. N. D.\& Folger, R. (2010). The relationship between ethical leadership and core job characteristics. Journal of Organizational Behavior, 31(2-3), 259-278.

Pligin, A. A. (2003). Person orientated education: history and practice. Moscow: $\mathrm{KSP}+$, pp. 432.

Ruben, B. D.; De Lisi, R.\&Gigliotti, R. A. (2016). A guide for leaders in higher education: Core concepts, competencies, and tools. Stylus Publishing, LLC.

Schwartz, S.\&Suyemoto, K. (2013). Creating change from the inside: Youth development within a youth community-organizing program. Journal of Community Psychology, 41(3), 341-358.

Shakir, R. (2009). Soft skills at the Malaysian institutes of higher learning. Asia Pacific Education Review, 10, 309 - 315.

Stensaker, B. (2015). Organizational identity as a concept for understanding university dynamics. Higher Education, 69(1), 103-115.

Unsar, A. S.\&Karalar, S. (2013). The effect of personality traits on leadership behaviors: A research on the students of business administration department. Economic Review - Journal of Economics and Business, 6, 45 - 56.

Von Eye, A. (2010). Developing the person-oriented approach - Theory and methods of analysis.Development and Psychopathology, 22, 277-285. 
Ward, P.\& Ellis, G. D. (2008).Characteristics of youth leadership that influence adolescent peers to follow.Journal of Park and Recreation Administration, 26(2), 78 94.

Webb, C. E. (2018). Culture, Leadership, and Organizational Learning in California Community Colleges: Exploring the Potential for Second Order Change.

Zamani-Gallaher, E. M. (2018). Book Review: Practical leadership in community colleges: Navigating today's challenges by Boggs. GR, \& McPhail, CJ. 